\title{
Charge Neutralization in the Core of Plasma Treatment
}

\author{
Djamel Ghernaout ${ }^{1,2}$ \\ ${ }^{1}$ Chemical Engineering Department, College of Engineering, University of Ha'il, Ha'il, Saudi Arabia \\ ${ }^{2}$ Chemical Engineering Department, Faculty of Engineering, University of Blida, Blida, Algeria \\ Email: djamel_andalus@hotmail.com
}

How to cite this paper: Ghernaout, D. (2020) Charge Neutralization in the Core of Plasma Treatment. Open Access Library Journal, 7: e6434.

https://doi.org/10.4236/oalib.1106434

Received: May 16, 2020

Accepted: June 7, 2020

Published: June 10, 2020

Copyright $\odot 2020$ by author(s) and Open Access Library Inc.

This work is licensed under the Creative Commons Attribution International License (CC BY 4.0).

http://creativecommons.org/licenses/by/4.0/

\begin{abstract}
At the COVID-19 time, viruses could easily contaminate humans, animals, and plants. In charge of several hospitalizations, many deaths, and widespread crop destruction, viruses lead to a considerable medical, economical, and biological burden. Several applied disinfection techniques are efficient and unfortunately possess inherent disadvantages. As a fresh, performant and green technology, cold plasma has attracted attention for its efficacy in viruses' killing. This work presents a brief summary of the late developments in the domain of applying cold plasma in dealing with viruses. The "plasma" term refers to any gas-discharged setup with ions and energetic electrons, where charged particles and plasma-generated highly reactive species dictate the physiochemical features of the whole system. When the electron gaining sufficient energy to defeating the electrostatic potential barrier, the electron will be stripped away to produce a free electron and a positively charged ion. Such a phenomenon is named ionization. This phenomenon is similar to the coagulation/flocculation $(\mathrm{C} / \mathrm{F})$ processes that are due to charge neutralization $(\mathrm{CN})$ and sweep flocculation (SF) mechanisms. Colloids may be inorganic (such as clay particles), organic (like humic particles and macromolecules), or biological (bacteria, viruses, etc.). The consequence of this smallness in size and mass and largeness in surface area is that in colloidal suspensions: gravitational effects are negligible and surface phenomena predominate. Hence, during C/F process, colloids are removed by $\mathrm{CN}$ and $\mathrm{SF}$ mechanisms which act on the anionic charge of the colloid by its neutralization prior to its removal by sedimentation/filtration. There is a $\mathrm{CN}$ mechanism dictated by the presence of positive ions formed through plasma utilization. Further research is requested to understand the $\mathrm{CN}$ mechanism related to plasma treatment and optimize such a promising technology.
\end{abstract}

\section{Subject Areas}

Chemical Engineering \& Technology, Electrochemistry 


\section{Keywords}

Coronavirus Disease 2019 (COVID-19), Cold Atmospheric-Pressure Plasmas (CAPs), Charge Neutralization (CN), Reactive Oxygen Species (ROSs), Reactive Nitrogen Species (RNSs), Water Treatment

\section{Introduction}

Famous as the fourth basic state of the matter aside from solid, liquid, and gas, plasma is an electroneutral mixture carrying several reactive radicals, diverse positive and negative particles, quanta of electromagnetic radiation, and strong electrical fields [1] [2] [3]. Through elevating energy using on the atoms in solid, arbitrary thermal motion of such atoms augments considerably and ultimately prevail the restrictive interactions among such atoms (such as ionic bonds in solid), conducting to the material transition from solid to liquid (Figure 1). Besides, when the atoms in liquid gained high-energy to prevail the constricted Van der Waals force from surroundings, the gas state could be attained. Certainly, the atoms' kinetic energy in the gas is much greater than that in solid and liquid. When the electron acquiring the high enough energy to conquering the electrostatic potential barrier, the electron will be stripped away to form a free electron and a positively charged ion, called ionization [1].

Following thermal equilibrium of the formed constituents, plasmas are largely categorized into two major classes: thermal plasmas (usually obtained at higher temperature and gas pressure circumstances) and cold plasmas (Figure 1(b)).

(a)

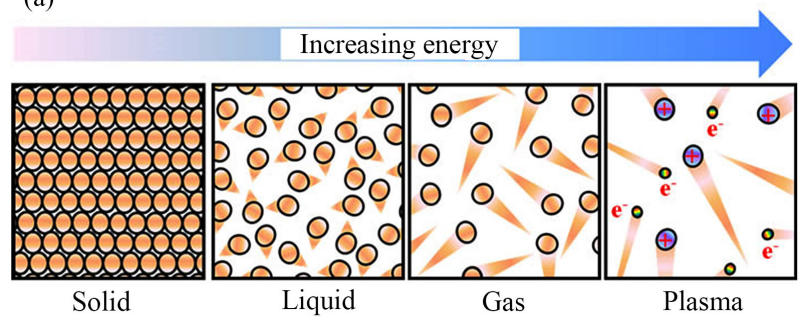

(b)

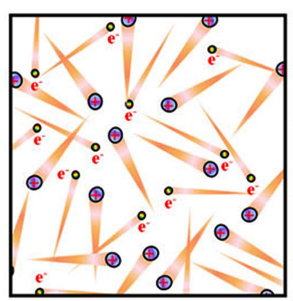

Thermal plasma

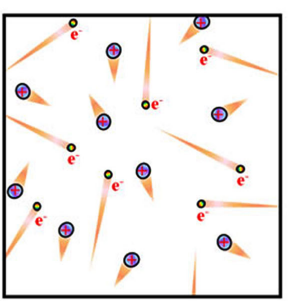

Cold plasma

Figure 1. Physical description of plasmas. (a) Schematic illustration of the four fundamental states of matter. The triangular tails represent the thermal motion strength of particles. (b) Schematic illustration of the thermal plasma and the cold plasma. Brown balls, violet balls, and iridescent balls represent the neutral atoms, the positively charged ions, and electrons, respectively [2]. 
When a gas is heated to sufficiently elevated temperature (usually about 20,000 K) to reach total ionization. This type of plasma could be designated as "thermal plasma”, in which all the constituents comprising ions, electrons, and chemical species are in thermodynamic equilibrium. Cold atmospheric-pressure plasmas (CAPs) possess electrons the temperature of which is considerably more important than that of other active and neutral species [4]. Such plasmas could be produced below ambient pressure and temperature employing easy setups comprising corona discharges, glow discharges, dielectric-barrier discharges (DBDs), and plasma jets [1] [2] [3].

Numerous chemical reactions could be hard, if not unfeasible, to realize employing traditional techniques. Such reactions can be allowed using CAPs [1]. With a large success, CAPs have been used in material processing, contaminant removal, biomedical implementations, etc. [1]. Thus, CAP is also an encouraging and interesting option to traditional radical originators.

\section{Plasma's Historical Background}

As aurora borealis and lightning, plasma takes place naturally through the globe. In lab-scale, it could be produced employing diverse techniques to study its suitable and singular features for different uses, from wound healing, selective cancer cell killing, surface decontamination and water sterilization, to sustainable food and green agriculture (Figure 2) [1]. The premature researches in electro-discharges were done by Ernst Siemens [5], in the 1850s, who proved the occurrence of DBDs. Langmuir, a century ago, proposed that the ions, electrons, and neutral particles in an ionized gas media can be viewed as a medium plasma, which is identical to the expression proposed and by Jan Purkinje. He participated in the description of a novel expression clear fluid that stays after removing all the corpuscular substances carrying in blood. The expression prevailed and now "plasma" usually alludes to any gas-discharged setup with ions and energetic electrons, where charged particles and plasma-generated highly reactive species dictate the physiochemical features of the whole system [1] [4].

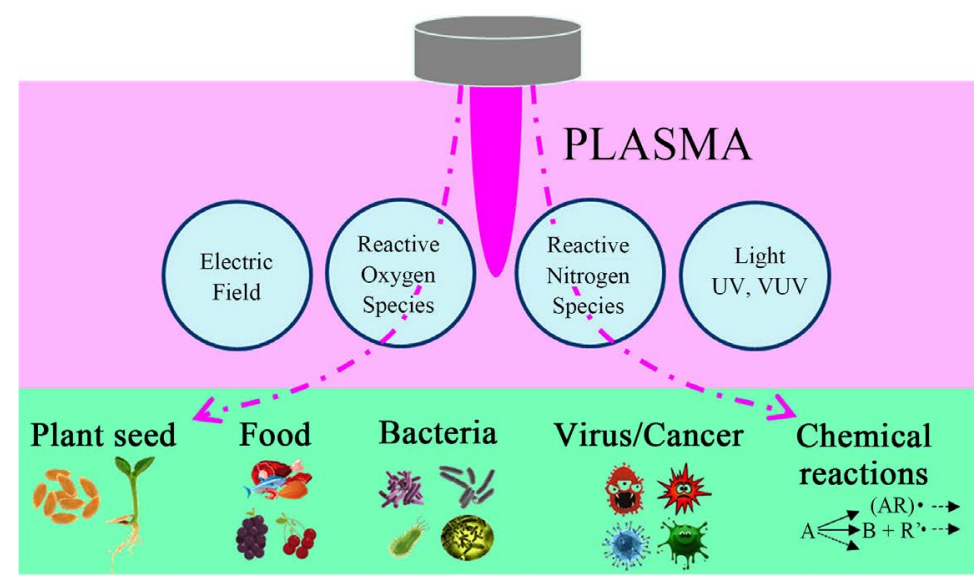

Figure 2. Constituents in CAP and their interactions with liquid for biotech utilizations [1]. 
A century ago, the physics of plasma has expanded as a separate and primal branch of study. For the first time, Townsend [1] studied the current flow over a gas, employing the concept of self-consistency due to the ionization balance in gaseous plasma [1]. Since the 1970s, plasma processing has been largely utilized to etch semiconductor or other sensitive materials or for material alterations [1]. In the following decades, numerous additional usages of CAP have arisen, mostly comprising chemical synthesis, wastewater treatment and water sterilization, plasma medicine and food preservation [1] [4].

\section{Plasma's Research Background}

To date, numerous reports on different implementations of CAPs show a quick expansion and an interesting capacity of such a novel interdisciplinary field. Indeed, CAPs could efficaciously neutralize a variety of pathogens [6] [7] [8], even highly resistant forms like bacterial spores and biofilms. Such performance renders CAPs greatly appropriate for sterilizing and disinfecting temperature-sensitive surfaces, medical equipment, air, water, and food [1]. Nevertheless, regardless of many observed favorable impacts of killing microorganisms [9] [10] [11] via CAPs application, their mechanisms with microbes stay not well comprehended. Further, numerous troubles stay to be resolved. Indeed, because kinds and levels of the constituents produced in CAP are a function of the electrode arrangement [12] [13] [14], excited voltages [15] [16] [17], production modes and the sorts of feeding gases employed to form plasma, the challenges remain to present novel CAP apparatuses that could ameliorate the proved CAPs action such as the levels of reactive oxygen species (ROSs) and reactive nitrogen species (RNSs) produced through actual CAP setups [1] [4].

\section{Cold Plasma as a Source of Reactive Species}

Through plasma application, ROSs formed mostly comprise hydrogen peroxide $\left(\mathrm{H}_{2} \mathrm{O}_{2}\right)$, hydroxyl radical $\left({ }^{\bullet} \mathrm{OH}\right)$, atomic oxygen, singlet-delta oxygen and superoxide $\left(\mathrm{O}_{2}^{-}\right)$; however, $\mathrm{RNSs}$ mostly carry nitrite $\left(\mathrm{NO}_{2}^{-}\right)$, nitrate $\left(\mathrm{NO}_{3}^{-}\right)$, nitric oxide (NO), atomic nitrogen $(\mathrm{N})$ and peryoxynitrite $\left(\mathrm{ONOO}^{-}\right)$[1]. The set of ROSs and RNSs has a crucial contribution to ecological hygiene and healthcare utilization in medicine, environment purification, food preservation, and safety [4].

To enhance the implementation of the plasma-founded setup, it is significant to understand the generation mechanisms of reactive chemical species in the liquid as well as to measure the level of such species. Such data could furnish a valuable insight for improving the CAPs formed impacts and dominating the distribution of ROSs and RNSs in water (Figure 3) [1]. From plasma to water, transferring reactivity mostly happens at the gas-liquid interface. Such a transfer is joined by several physicochemical phenomena involving gaseous particle collisions, mass transfer, sputtering and photolysis formed via UV photons. As a rule, the reactive chemical species are originally produced in a gas-phase plasma. 


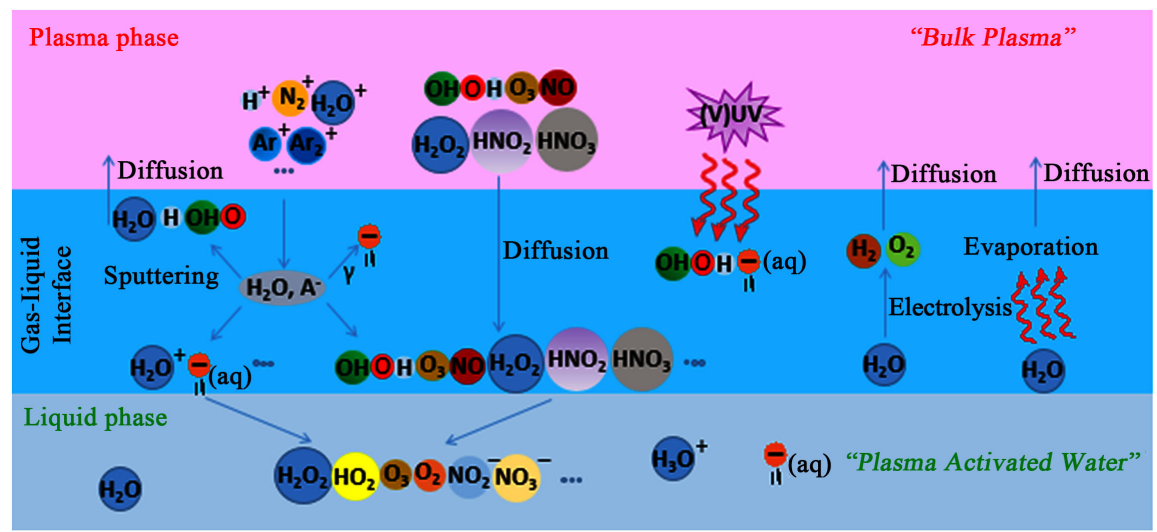

Figure 3. Symbolic depiction of the multi-phase transfer of reactive oxygen species (ROSs) and reactive nitrogen species (RNSs) towards water [1].

A portion of such gaseous species is then transported to the plasma-liquid interface, entering the gas-liquid interface and then reacting with the water molecules (Figure 3). Researchers [18] anticipated the distribution of reactive species in water stimulated via CAP by employing a neutral mass transport model for gaseous plasma-liquid systems [1] [4].

\subsection{Hydrogen Peroxide $\left(\mathrm{H}_{2} \mathrm{O}_{2}\right)$}

As one of the main important ROSs, hydrogen peroxide possesses several roles in cell redox signaling mechanisms. This is why it had been largely utilized in medicine and agriculture [1]. Several scientists worked on $\mathrm{H}_{2} \mathrm{O}_{2}$ generated by plasma as a fresh technique for demobilizing microbes and treating cancer, likely thanks to its stability, long life-time, and its comparatively simple detectability between such plasma-generated species. Hydrogen peroxide could be produced through numerous routes. Hydrogen peroxide formation mostly implicates the integration of ${ }^{\bullet} \mathrm{OH}$ generated from the electronically dissociated water molecules. In the system of water vapor stimulated by helium plasma, $\mathrm{H}_{2} \mathrm{O}_{2}$ mostly originated from the recombination of ${ }^{\bullet} \mathrm{OH}[1]$ [4].

\subsection{Ozone $\left(\mathrm{O}_{3}\right)$}

Solubilized in water, ozone is viewed as a powerful antimicrobial oxidant agent [10]. In fact, it possesses the highest oxidation redox potential (ORP) between usual oxidants $\left(E^{\circ}=2.07 \mathrm{~V}\right)$, comprising chlorine, chlorine dioxide, hydrogen peroxide and permanganate [1]. Following being generated in the gas phase, $\mathrm{O}_{3}$ could transport through the interface into water. Moreover, it is also probable to form $\mathrm{O}_{3}$ directly in water, like in the instance of plasma discharge formed in oxygen-containing bubbles [4].

\subsection{Nitric Oxide (NO)}

As an omnipresent signaling molecule observed in numerous organisms, nitric oxide (NO) has lately been presented as an encouraging antimicrobial agent. It can be quantified in the stimulated media phase and directly in the gas phase of 
non-thermal plasma. Such a feature renders it a valuable agent for clinical utilization [1]. Scientists [18] suggested a model showing the case for a plasma jet interacting with liquid, in which NO could not be observed in the bulk liquid, only at the gas-liquid interface. Such a model specified that long-lived species were mainly generated at the interface either via direct solvation or via secondary reactions in water, for instance, NO formed from the gas phase plasma [4].

\subsection{Peroxynitrite}

Peroxynitrite comprises both $\mathrm{OONO}^{-}$and $\mathrm{ONOOH}$ species. Peroxynitrite contributes biologically in controlling health and disease in organism. Several investigations on bioactivity of plasma stimulated water proposed probable generation mechanisms of peroxynitrite. Researchers proposed that chemical responses among nitrite and hydrogen peroxide could conduct to the constant formation of peroxynitrite that is directly in charge of killing microbes [1] [4].

\subsection{Hydroxyl Radical $\left({ }^{\circ} \mathrm{OH}\right)$ and Superoxide $\left(\mathrm{O}_{2}^{--}\right)$}

Working as a precursor of $\mathrm{H}_{2} \mathrm{O}_{2}$ in water, ${ }^{\bullet} \mathrm{OH}$ is a crucial ROS possessing a powerful oxidizing potential $\left(E^{\circ}=2.85 \mathrm{~V}\right)$ in water and at the interface among gas and water [19] [20]. Such elevated potential explains the lifetime of ${ }^{\bullet} \mathrm{OH}$ that is $\sim 200 \mu \mathrm{s}$ in the gaseous phase and around some ns in water. Therefore, in order to let ${ }^{\bullet} \mathrm{OH}$ enter in reactions directly with pathogens, it has to be formed in the frontal vicinity of the microbe [1].

Superoxide $\left(\mathrm{O}_{2}^{--}\right)$is an additional fundamental radical produced from plasma-liquid interactions [1]. It could be formed via the deprotonation of the hydroperoxyl radical ${ }^{\bullet} \mathrm{OOH}$ that could be produced from $\mathrm{OH}$ interacting with $\mathrm{O}_{3}$ or from the responses of $\mathrm{O}_{2}$ with greatly energetic electrons [4].

\section{Cold Plasma in Water Treatment}

During the last seventy years, there has been a spectacular augmentation in the number of organic contaminants (volatile organic compounds [21] [22] [23], pharmaceuticals [24] [25] [26], organic dyes [27] [28] [29], etc.) and considerably persistent pathogens existing in ecosystems [30] [31] [32], therefore constituting a grave worry for the public health [33] [34] [35]. Lately, a huge elevation in the economic loss and human deaths of community-onset poisonous chemical and healthcare-associated contagions (pathogenic microorganisms such as severe acute respiratory syndrome coronavirus 2 (SARS-CoV-2)) [1] [36] [37].

As an encouraging wastewater treatment technology [38] [39] [40], advanced oxidation processes (AOPs) run via in situ formations of greatly responsive oxidants like ${ }^{\circ} \mathrm{OH}\left(E^{\circ}=2.85 \mathrm{~V}\right), \mathrm{H}_{2} \mathrm{O}_{2}\left(E^{\circ}=1.7 \mathrm{~V}\right)$ and $\mathrm{O}_{3}\left(E^{\circ}=2.07 \mathrm{~V}\right)$. Numerous versions of AOP techniques have been proposed like sonolysis, $\mathrm{O}_{3} / \mathrm{UV}$, photo-Fenton, and photo-catalysis [1] [4]. Nevertheless, the capacity of such techniques stays restricted due to the insufficiency of the amount of the oxidants [41] [42] [43].

Twenty years ago, non-thermal atmospheric pressure plasmas generated at near room temperatures have attracted an increasing interest (Figure 4). Electric 


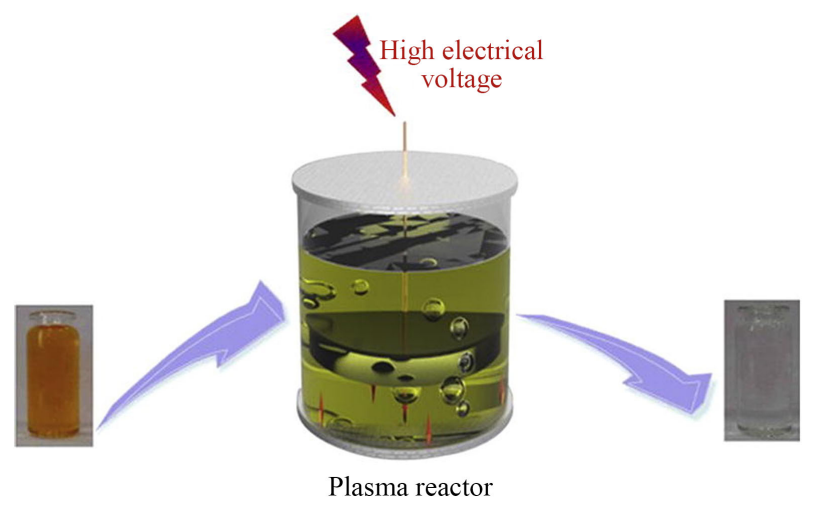

Figure 4. Electrical discharge plasma could be formed in a device via introducing high-electrical voltage [51].

discharge plasmas could be produced following discharge circumstances like gas sort, gas flow rate, discharge frequency, power supply, and applied voltage. Such plasmas mostly carry electrons, ions, free radicals, UV light [44] [45] [46], and electric field [47] [48] [49]. There numerous versions for producing plasma comprising dielectric-barrier discharge (DBD), arc discharge, spark discharge, corona discharge, and plasma jets. All these techniques have been used in dealing with pollutant removal [1] [4] [50].

Researchers [52] degraded successfully humic acid [53] [54] [55] employing a gas-phase surface discharge plasma apparatus with the plasma treatment during $40 \mathrm{~min}$ at the applied discharge voltage of $23.0 \mathrm{kV}$. Such outstanding performance is mostly affected to ${ }^{\circ} \mathrm{OH}$ and $\mathrm{O}_{3}[1]$ [4].

A deep discussion of the CAPs implementation in the water treatment is suggested by Zhou [1].

\section{Cold Plasma for Killing Viruses}

Every year, pathogenic viruses generate tens to hundreds of millions of plant, animal, and human infections leading to increased crop losses and numerous deaths [56] [57] [58]. As a consequence, neutralizing harmful viruses is vital for a better quality of life [59] [60] [61]. Viruses could be spread directly from one contaminated person to another, or indirectly through polluted intermediates, like surfaces, objects, air, food, and water [59] [60] [62]. Diffusion through polluted surfaces and aerosols has been depicted to be of considerable significance in the COVID-19 pandemic, provoked by severe acute respiratory syndrome coronavirus 2 (SARS-CoV-2) [4] [63] [64]. Water and wastewater are as well turning into an essential diffusion pathway for viruses [59] [65] [66]. This has worsen due to global warming, integrated with inefficacious virus elimination via conventional water and wastewater treatments, and water reuse for irrigation aims [67] [68]. Different killing techniques are employed to stop the viral transmission in ecosystems even if the best technology stays to be determined [69] [70] [71]. Therefore, there is an acute necessity for an environmentally-friendly technique that forms neither waste nor toxic by-products [72] [73] [74], does 
not inject poisonous chemicals [66] [75] [76], is simple and secure to run, and is as well performant in neutralizing pathogens especially viruses [59] [60] [77]. Cold plasma treatments for killing viruses seem to meet all of such characteristics.

As seen above, plasma is a partially or completely ionized gas in which the atoms and/or molecules are stripped of their outer-shell electrons. Among its combined compounds, ultraviolet (UV) radiation and ROSs and/or RNSs furnish the most significant antimicrobial tools [4] [78] [79]. UV could deteriorate nucleic acids and ROSs and RNSs could oxidize nucleic acids, proteins, and lipids, with varying affinities following the microorganisms' species present in water [80] [81] [82]. Such intrinsic features of cold plasma have attracted large investigations on its application for neutralizing microbes [56].

In fact, every investigation of cold plasma implementation for neutralizing viruses is specific. This is attributed to the fact that scientists either utilize a particular plasma source (like DBD, plasma (micro)jet) with various properties (such as power, gas, treatment period), or they remedy distinct water volumes (from microliters to several milliliters), matrices (like water, other solutions, surfaces, cells), and viruses (surrogates of human viruses, human, animal and plant viruses). This large variety complicates the direct juxtaposition of such researches and the establishment of mechanistic reasoning [4] [56].

Enteric viruses like norovirus, adenovirus, and hepatitis A virus have been killed via cold plasma treatments. Dealing with human viruses could generate grave health dangers; therefore those tests need hard requirements at the lab-level. For such considerations, such viruses are frequently substituted via surrogate viruses. Both enteric viruses and their surrogates have been efficiently neutralized in water. Killing a selected surrogate virus is found more effective than that of the target enteric virus [4] [56]. This is could be related to the impacts of cold plasma on such surrogates that might not easily mirror their influences on the enteric virus counterparts, and have to be explained with caution.

\section{Charge Neutralization (CN) as the Main Mechanism of Plasma Treatment}

As mentioned previously, the "plasma" term refers to any gas-discharged setup with ions and energetic electrons, where charged particles and plasma-generated highly reactive species dictate the physiochemical features of the whole system [1] [4]. When the electron gaining sufficient energy to defeating the electrostatic potential barrier, the electron will be stripped away to produce a free electron and a positively charged ion. Such a phenomenon is named ionization [1]. Further, as aforesaid, there are two forms of plasma: thermal and cold (Figure 1(b)). The difference between such forms is that in the first version there are more electrons and positive ions than in the second one, as shown in Figure 1(b).

This phenomenon is similar to the coagulation/flocculation $(\mathrm{C} / \mathrm{F})$ processes, which are mostly due to charge neutralization (CN) and sweep flocculation (SF) mechanisms [55]. Colloids are very small particles that have an extremely large 
surface area. Colloids may be inorganic (such as clay particles), organic (like humic particles and macromolecules), or biological (bacteria, viruses, etc.). The consequence of this smallness in size and mass and largeness in surface area is that in colloidal suspensions: gravitational effects are negligible and surface phenomena predominate [55]. Hence, during C/F process, colloids are removed by $\mathrm{CN}$ and SF mechanisms which act on the anionic charge of the colloid by its neutralization prior to its removal by sedimentation/filtration [55]. As the same mostly negatively charged pollutants are present when plasma treatment is applied, there is a $\mathrm{CN}$ mechanism dictated by the presence of positive ions formed through plasma utilization. Further research is requested to understand $\mathrm{CN}$ and SF mechanisms related to plasma treatment.

\section{Conclusions}

From this work, the following conclusions can be drawn:

1) Cold plasma is one of the most performant and environmentally-friendly technologies for neutralizing viruses. Implementing such a technique will conduct to decreased human contaminations via water [83] [84] [85]. It remains fundamental to assess the possible unfavorable genotoxic and cytotoxic impacts of plasma-activated water on humans. Moreover, a practical implementation of cold plasma could present a valuable option to viral eruptions (SARS-CoV-2 is present) [4] [56].

2) The precise mechanisms of the cold plasma functionality in scaled-up devices stay needing more insights. In this context, it is requested to understand the flux of reactive species (ROSs and RNSs vs. radiation) on the virus's surface, the possibility for the response of a specific kind of ROSs/RNSs with the virus. An additional challenge is a manner by which scaling up cold plasma devices without touching the configuration and quantity of ROSs/RNSs attained at a lab-scale. Employing numerous small setups, placed in parallel, could elevate the quantity of treated water by keeping the water plasma configuration [4] [56] [86].

3) Applying cold plasma could the place of the traditional chemical techniques since it does not generate large waste and could efficaciously demobilize viruses

[56]. Implementing cold plasma will possibly assist in dealing with the shortage of drinking water and the harmful impacts of pandemics such as COVID-19 [87]. Merging cold plasma with additional performant methods, such as electrochemical technology and membrane filtration, can assist in eliminating viruses [4].

\section{Acknowledgements}

This research has been funded by the Research Deanship of University of Ha'il, Saudi Arabia, through the Project RG-191190.

\section{Conflicts of Interest}

The author declares no conflicts of interest regarding the publication of this paper. 


\section{References}

[1] Zhou, R. (2019) Direct and Indirect Activation of Biological Objects Using Cold Atmospheric Plasma. PhD Thesis, Queensland University of Technology, Brisbane City.

[2] Yan, D., Sherman, J.H. and Keidar, M. (2017) Cold Atmospheric Plasma, a Novel Promising Anti-Cancer Treatment Modality. Oncotarget, 8, 15977-15995. https://doi.org/10.18632/oncotarget.13304

[3] Lu, X., Naidis, G.V., Laroussi, M., Reuter, S., Graves, D.B. and Ostrikov, K. (2016) Reactive Species in Non-Equilibrium Atmospheric-Pressure Plasmas: Generation, Transport, and Biological Effects. Physics Reports, 630, 1-84. https://doi.org/10.1016/j.physrep.2016.03.003

[4] Ghernaout, D. and Elboughdiri, N. (2020) Disinfecting Water: Plasma Discharge for Removing Coronaviruses. Open Access Library Journal, 7, e6314. https://doi.org/10.4236/oalib.1106314

[5] Siemens, W. (1857) Ueber die elektrostatische Induction und die verzögerung des stroms in flaschendrähten. Annalen der Physik, 102, 66. https://doi.org/10.1002/andp.18571780905

[6] Ghernaout, D. and Elboughdiri, N. (2020) Strategies for Reducing Disinfection By-Products Formation during Electrocoagulation. Open Access Library Journal, 7, e6076. https://doi.org/10.4236/oalib.1106076

[7] Ghernaout, D. and Elboughdiri, N. (2020) Electrocoagulation Process in the Context of Disinfection Mechanism. Open Access Library Journal, 7, e6083.

[8] Ghernaout, D. and Elboughdiri, N. (2020) Disinfection By-Products: Presence and Elimination in Drinking Water. Open Access Library Journal, 7, e6140.

[9] Ghernaout, D. and Elboughdiri, N. (2020) Controlling Disinfection By-Products Formation in Rainwater: Technologies and Trends. Open Access Library Journal, 7, e6162. https://doi.org/10.4236/oalib.1106162

[10] Ghernaout, D. and Elboughdiri, N. (2020) Towards Enhancing Ozone Diffusion for Water Disinfection-Short Notes. Open Access Library Journal, 7, e6253.

[11] Ghernaout, D., Elboughdiri, N., Ghareba, S. and Salih, A. (2020) Disinfecting Water with the Carbon Fiber-Based Flow-Through Electrode System (FES): Towards Axial Dispersion and Velocity Profile. Open Access Library Journal, 7, e6238. https://doi.org/10.4236/oalib.1106238

[12] Ghernaout, D., Elboughdiri, N., Alghamdi, A. and Ghernaout, B. (2020) Trends in Decreasing Disinfection By-Products Formation during Electrochemical Technologies. Open Access Library Journal, 7, e6337. https://doi.org/10.4236/oalib.1106337

[13] Ghernaout, D., Badis, A., Ghernaout, B. and Kellil, A. (2008) Application of Electrocoagulation in Escherichia coli Culture and Two Surface Waters. Desalination, 219, 118-125. https://doi.org/10.1016/j.desal.2007.05.010

[14] Belhout, D., Ghernaout, D., Djezzar-Douakh, S. and Kellil, A. (2010) Electrocoagulation of a Raw Water of Ghrib Dam (Algeria) in Batch Using Iron Electrodes. Desalination and Water Treatment, 16, 1-9. https://doi.org/10.5004/dwt.2010.1081

[15] Ghernaout, D., Benblidia, C. and Khemici, F. (2015) Microalgae Removal from Ghrib Dam (Ain Defla, Algeria) Water by Electroflotation Using Stainless Steel Electrodes. Desalination and Water Treatment, 54, 3328-3337. https://doi.org/10.1080/19443994.2014.907749

[16] Ghernaout, D., Naceur, M.W. and Ghernaout, B. (2011) A Review of Electrocoagulation as a Promising Coagulation Process for Improved Organic and Inorganic 
Matters Removal by Electrophoresis and Electroflotation. Desalination and Water Treatment, 28, 287-320. https://doi.org/10.5004/dwt.2011.1493

[17] Ghernaout, D. and Elboughdiri, N. (2020) Electrochemical Technology for Wastewater Treatment: Dares and Trends. Open Access Library Journal, 7, e6020.

[18] Verlackt, C.C.W., Van Boxem, W. and Bogaerts, A. (2018) Transport and Accumulation of Plasma Generated Species in Aqueous Solution. Physical Chemistry Chemical Physics, 20, 6845-6859. https://doi.org/10.1039/C7CP07593F

[19] Ghernaout, D., Elboughdiri, N. and Ghareba, S. (2020) Fenton Technology for Wastewater Treatment: Dares and Trends. Open Access Library Journal, 7, e6045. https://doi.org/10.4236/oalib.1106045

[20] Ghernaout, D., Alghamdi, A. and Ghernaout, B. (2019) Electrocoagulation Process: A Mechanistic Review at the Dawn of Its Modeling. Journal of Environmental Science and Allied Research, 2, 51-67. https://doi.org/10.29199/2637-7063/ESAR-201019

[21] Ghernaout, D. and Elboughdiri, N. (2019) Water Reuse: Emerging Contaminants Elimination-Progress and Trends. Open Access Library Journal, 6, e5981.

[22] Ghernaout, D. (2017) Water Reuse (WR): The Ultimate and Vital Solution for Water Supply Issues. International Journal of Sustainable Development Research, 3, 36-46. https://doi.org/10.11648/j.ijsdr.20170304.12

[23] Ghernaout, D., Alshammari, Y., Alghamdi, A., Aichouni, M., Touahmia, M. and Ait Messaoudene, N. (2018) Water Reuse: Extenuating Membrane Fouling in Membrane Processes. International Journal of Environmental Chemistry, 2, 1-12. https://doi.org/10.11648/j.ajche.20180602.12

[24] Ghernaout, D. and Elboughdiri, N. (2020) Should We Forbid the Consumption of Antibiotics to Stop the Spread of Resistances in Nature? Open Access Library Journal, 7, e6138.

[25] Ghernaout, D., Elboughdiri, N. and Al Arni, S. (2019) Water Reuse (WR): Dares, Restrictions, and Trends. Applied Engineering, 3, 159-170.

[26] Ghernaout, D., Elboughdiri, N. and Ghareba, S. (2019) Drinking Water Reuse: One-Step Closer to Overpassing the "Yuck Factor". Open Access Library Journal, 6, e5895. https://doi.org/10.4236/oalib.1105895

[27] Ghernaout, D. and Elboughdiri, N. (2020) Eliminating Cyanobacteria and Controlling Algal Organic Matter-Short Notes. Open Access Library Journal, 7, e6252. https://doi.org/10.4236/oalib.1106252

[28] Ghernaout, D., Elboughdiri, N., Ghareba, S. and Salih, A. (2020) Coagulation Process for Removing Algae and Algal Organic Matter-An Overview. Open Access Library Journal, 7, e6272. https://doi.org/10.4236/oalib.1106272

[29] Ghernaout, D., Ghernaout, B. and Kellil, A. (2009) Natural Organic Matter Removal and Enhanced Coagulation as a Link between Coagulation and Electrocoagulation. Desalination and Water Treatment, 2, 203-222. https://doi.org/10.5004/dwt.2009.116

[30] Ghernaout, D., Elboughdiri, N. and Alghamdi, A. (2019) Direct Potable Reuse: The Singapore NEWater Project as a Role Model. Open Access Library Journal, 6, e5980. https://doi.org/10.4236/oalib.1105980

[31] Ghernaout, D. and Elboughdiri, N. (2020) On the Treatment Trains for Municipal Wastewater Reuse for Irrigation. Open Access Library Journal, 7, e6088.

[32] Ghernaout, D. (2018) Increasing Trends towards Drinking Water Reclamation from Treated Wastewater. World Journal of Applied Chemistry, 3, 1-9. https://doi.org/10.11648/j.wjac.20180301.11 
[33] Ghernaout, D., Ghernaout, B. and Naceur, M.W. (2011) Embodying the Chemical Water Treatment in the Green Chemistry-A Review. Desalination, 271, 1-10. https://doi.org/10.1016/j.desal.2011.01.032

[34] Ghernaout, D. and Naceur, M.W. (2011) Ferrate(VI): In Situ Generation and Water Treatment-A Review. Desalination and Water Treatment, 30, 319-332. https://doi.org/10.5004/dwt.2011.2217

[35] Ghernaout, D. (2017) Environmental Principles in the Holy Koran and the Sayings of the Prophet Muhammad. American Journal of Environmental Protection, 6, 75-79. https://doi.org/10.11648/j.ajep.20170603.13

[36] Ghernaout, D. and Elboughdiri, N. (2020) Antibiotics Resistance in Water Mediums: Background, Facts, and Trends. Applied Engineering, 4, 1-6. https://doi.org/10.4236/oalib.1106003

[37] Ghernaout, D. and Elboughdiri, N. (2020) Removing Antibiotic-Resistant Bacteria (ARB) Carrying Genes (ARGs): Challenges and Future Trends. Open Access Library Journal, 7, e6003. https://doi.org/10.4236/oalib.1106003

[38] Ghernaout, D., Alshammari, Y. and Alghamdi, A. (2018) Improving Energetically Operational Procedures in Wastewater Treatment Plants. International Journal of Advances in Applied Sciences, 5, 64-72. https://doi.org/10.21833/ijaas.2018.09.010

[39] Al Arni, S., Amous, J. and Ghernaout, D. (2019) On the Perspective of Applying of a New Method for Wastewater Treatment Technology: Modification of the Third Traditional Stage with Two Units, One by Cultivating Microalgae and Another by Solar Vaporization. International Journal of Environmental Sciences \& Natural Resources, 16, Article ID: 555934. https://doi.org/10.19080/IJESNR.2019.16.555934

[40] Ghernaout, D. (2019) Reviviscence of Biological Wastewater Treatment-A Review. Applied Engineering, 3, 46-55.

[41] Ghernaout, D. (2019) Electrocoagulation Process for Microalgal Biotechnology-A Review. Applied Engineering, 3, 85-94.

[42] Ghernaout, D. (2019) Greening Cold Fusion as an Energy Source for Water Treatment Distillation-A Perspective. American Journal of Quantum Chemistry and Molecular Spectroscopy, 3, 1-5.

[43] Ghernaout, D. and Elboughdiri, N. (2019) Upgrading Wastewater Treatment Plant to Obtain Drinking Water. Open Access Library Journal, 6, e5959. https://doi.org/10.4236/oalib.1105959

[44] Ghernaout, D. and Elboughdiri, N. (2020) Solar Treatment in the Core of the New Disinfection Technologies. Chemical Science \& Engineering Research, 2, 6-11.

[45] Ghernaout, D., Alghamdi, A., Touahmia, M., Aichouni, M. and Ait Messaoudene, N. (2018) Nanotechnology Phenomena in the Light of the Solar Energy. Journal of Energy, Environmental \& Chemical Engineering, 3, 1-8. https://doi.org/10.11648/j.jeece.20180301.11

[46] Ghernaout, D., Boudjemline, A. and Elboughdiri, N. (2020) Electrochemical Engineering in the Core of the Dye-Sensitized Solar Cells (DSSCs). Open Access Library Journal, 7, e6178. https://doi.org/10.4236/oalib.1106178

[47] Ghernaout, D. and Elboughdiri, N. (2020) An Insight in Electrocoagulation Process through Current Density Distribution (CDD). Open Access Library Journal, 7, e6142.

[48] Ghernaout, D., Ghernaout, B., Saiba, A., Boucherit, A. and Kellil, A. (2009) Removal of Humic Acids by Continuous Electromagnetic Treatment Followed by Electrocoagulation in Batch Using Aluminium Electrodes. Desalination, 239, 295-308. https://doi.org/10.1016/j.desal.2008.04.001 
[49] Ghernaout, D., Ghernaout, B. and Boucherit, A. (2008) Effect of pH on Electrocoagulation of Bentonite Suspensions in Batch Using Iron Electrodes. Journal of Dispersion Science and Technology, 29, 1272-1275. https://doi.org/10.1080/01932690701857483

[50] Ghernaout, D., Ghernaout, B., Boucherit, A., Naceur, M.W., Khelifa, A. and Kellil, A. (2009) Study on Mechanism of Electrocoagulation with Iron Electrodes in Idealised Conditions and Electrocoagulation of Humic Acids Solution in Batch Using Aluminium Electrodes. Desalination and Water Treatment, 8, 91-99. https://doi.org/10.5004/dwt.2009.668

[51] Jiang, B., Zheng, J., Qiu, S., Wu, M., Zhang, Q., Yan, Z. and Xue, Q. (2014) Review on Electrical Discharge Plasma Technology for Wastewater Remediation. Chemical Engineering Journal, 236, 348-368. https://doi.org/10.1016/j.cej.2013.09.090

[52] Wang, T., Qu, G., Ren, J., Yan, Q., Sun, Q., Liang, D. and Hu, S. (2016) Evaluation of the Potentials of Humic Acid Removal in Water by Gas Phase Surface Discharge Plasma. Water Research, 89, 28-38. https://doi.org/10.1016/j.watres.2015.11.039

[53] Ghernaout, D., Mariche, A., Ghernaout, B. and Kellil, A. (2010) Electromagnetic Treatment-Bi-Electrocoagulation of Humic Acid in Continuous Mode Using Response Surface Method for Its Optimization and Application on Two Surface Waters. Desalination and Water Treatment, 22, 311-329.

https://doi.org/10.5004/dwt.2010.1120

[54] Ghernaout, D., Irki, S. and Boucherit, A. (2014) Removal of $\mathrm{Cu}^{2+}$ and $\mathrm{Cd}^{2+}$, and Humic Acid and Phenol by Electrocoagulation Using Iron Electrodes. Desalination and Water Treatment, 52, 3256-3270. https://doi.org/10.1080/19443994.2013.852484

[55] Ghernaout, D. and Ghernaout, B. (2012) Sweep Flocculation as a Second Form of Charge Neutralisation-A Review. Desalination and Water Treatment, 44, 15-28. https://doi.org/10.1080/19443994.2012.691699

[56] Filipić, A., Gutierrez-Aguirre, I., Primc, G., Mozetič, M. and Dobnik, D. (2020) Cold Plasma, a New Hope in the Field of Virus Inactivation. Trends in Biotechnology. https://doi.org/10.1016/j.tibtech.2020.04.003

[57] Ghernaout, D. and Elboughdiri, N. (2020) Foresight Look on the Disinfection By-Products Formation. Open Access Library Journal, 7, e6349.

[58] Ghernaout, D., Naceur, M.W. and Aouabed, A. (2011) On the Dependence of Chlorine By-Products Generated Species Formation of the Electrode Material and Applied Charge during Electrochemical Water Treatment. Desalination, 270, 9-22. https://doi.org/10.1016/j.desal.2011.01.010

[59] Ghernaout, D. (2019) Virus Removal by Electrocoagulation and Electrooxidation: New Findings and Future Trends. Journal of Environmental Science and Allied Research, 2019, 85-90.

[60] Ghernaout, D. and Elboughdiri, N. (2020) Environmental Engineering for Stopping Viruses Pandemics. Open Access Library Journal, 7, e6299.

[61] Ghernaout, D. and Ghernaout, B. (2012) On the Concept of the Future Drinking Water Treatment Plant: Algae Harvesting from the Algal Biomass for Biodiesel Production-A Review. Desalination and Water Treatment, 49, 1-18. https://doi.org/10.1080/19443994.2012.708191

[62] Ghernaout, D., Moulay, S., Ait Messaoudene, N., Aichouni, M., Naceur, M.W. and Boucherit, A. (2014) Coagulation and Chlorination of NOM and Algae in Water Treatment: A Review. International Journal of Environmental Monitoring and Analysis, 2, 23-34. https://doi.org/10.11648/j.ijema.s.2014020601.14 
[63] Ghernaout, D., Badis, A., Braikia, G., Matâam, N., Fekhar, M., Ghernaout, B. and Boucherit, A. (2017) Enhanced Coagulation for Algae Removal in a Typical Algeria Water Treatment Plant. Environmental Engineering and Management Journal, 16, 2303-2315. https://doi.org/10.30638/eemj.2017.238

[64] Ghernaout, D. (2017) Water Treatment Chlorination: An Updated Mechanistic Insight Review. Journal of Chemical Research, 2, 125-138.

[65] Ghernaout, D. (2019) Greening Electrocoagulation Process for Disinfecting Water. Applied Engineering, 3, 27-31.

[66] Ghernaout, D. (2019) Disinfection via Electrocoagulation Process: Implied Mechanisms and Future Tendencies. EC Microbiology, 15, 79-90.

[67] Ghernaout, D. (2017) Microorganisms' Electrochemical Disinfection Phenomena. EC Microbiology, 9, 160-169.

[68] Ghernaout, D., Alghamdi, A. and Ghernaout, B. (2019) Microorganisms' Killing: Chemical Disinfection vs. Electrodisinfection. Applied Engineering, 3, 13-19.

[69] Ghernaout, D., Aichouni, M. and Touahmia, M. (2019) Mechanistic Insight into Disinfection by Electrocoagulation-A Review. Desalination and Water Treatment, 141, 68-81. https://doi.org/10.5004/dwt.2019.23457

[70] Ghernaout, D. (2019) Electrocoagulation and Electrooxidation for Disinfecting Water: New Breakthroughs and Implied Mechanisms. Applied Engineering, 3, 125-133.

[71] Ghernaout, D. and Elboughdiri, N. (2019) Electrocoagulation Process Intensification for Disinfecting Water-A Review. Applied Engineering, 3, 140-147.

[72] Boucherit, A., Moulay, S., Ghernaout, D., Al-Ghonamy, A.I., Ghernaout, B., Naceur, M.W., Ait Messaoudene, N., Aichouni, M., Mahjoubi, A.A. and Elboughdiri, N.A. (2015) New Trends in Disinfection By-Products Formation upon Water Treatment. Journal of Research \& Developments in Chemistry, 2015, Article ID: 628833. https://doi.org/10.5171/2015.628833

[73] Ghernaout, D. (2018) Disinfection and DBPs Removal in Drinking Water Treatment: A Perspective for a Green Technology. International Journal of Advances in Applied Sciences, 5, 108-117. https://doi.org/10.21833/ijaas.2018.02.018

[74] Ghernaout, D., Touahmia, M. and Aichouni, M. (2019) Disinfecting Water: Electrocoagulation as an Efficient Process. Applied Engineering, 3, 1-12.

[75] Ghernaout, D. and Elboughdiri, N. (2019) Iron Electrocoagulation Process for Disinfecting Water-A Review. Applied Engineering, 3, 154-158.

[76] Ghernaout, D. and Elboughdiri, N. (2019) Mechanistic Insight into Disinfection Using Ferrate(VI). Open Access Library Journal, 6, e5946.

[77] Ghernaout, D. and Elboughdiri, N. (2019) Water Disinfection: Ferrate(VI) as the Greenest Chemical-A Review. Applied Engineering, 3, 171-180.

[78] Ghernaout, D. and Elboughdiri, N. (2020) UV-C/ $\mathrm{H}_{2} \mathrm{O}_{2}$ and Sunlight $/ \mathrm{H}_{2} \mathrm{O}_{2}$ in the Core of the Best Available Technologies for Dealing with Present Dares in Domestic Wastewater Reuse. Open Access Library Journal, 7, e6161. https://doi.org/10.4236/oalib.1106161

[79] Ghernaout, D. (2013) Advanced Oxidation Phenomena in Electrocoagulation Process: A Myth or a Reality? Desalination and Water Treatment, 51, 7536-7554. https://doi.org/10.1080/19443994.2013.792520

[80] Ghernaout, D. and Elboughdiri, N. (2020) Vacuum-UV Radiation at $185 \mathrm{~nm}$ for Disinfecting Water. Chemical Science \& Engineering Research, 2, 12-17. 
[81] Ghernaout, D. and Elboughdiri, N. (2020) Advanced Oxidation Processes for Wastewater Treatment: Facts and Future Trends. Open Access Library Journal, 7, e6139.

[82] Ghernaout, D., Elboughdiri, N., Ghareba, S. and Salih, A. (2020) Electrochemical Advanced Oxidation Processes (EAOPs) for Disinfecting Water-Fresh Perspectives. Open Access Library Journal, 7, e6257. https://doi.org/10.4236/oalib.1106257

[83] Ghernaout, D. (2018) Magnetic Field Generation in the Water Treatment Perspectives: An Overview. International Journal of Advances in Applied Sciences, 5, 193-203. https://doi.org/10.21833/ijaas.2018.01.025

[84] Ghernaout, D., Aichouni, M. and Alghamdi, A. (2018) Applying Big Data (BD) in Water Treatment Industry: A New Era of Advance. International Journal of Advances in Applied Sciences, 5, 89-97. https://doi.org/10.21833/ijaas.2018.03.013

[85] Alshammari, Y., Ghernaout, D., Aichouni, M. and Touahmia, M. (2018) Improving Operational Procedures in Riyadh's (Saudi Arabia) Water Treatment Plants Using Quality Tools. Applied Engineering, 2, 60-71.

[86] Ghernaout, D. and Ghernaout, B. (2010) From Chemical Disinfection to Electrodisinfection: The Obligatory Itinerary? Desalination and Water Treatment, 16, 156-175. https://doi.org/10.5004/dwt.2010.1085

[87] Ghernaout, D. and Elboughdiri, N. (2020) Urgent Proposals for Disinfecting Hospital Wastewaters during COVID-19 Pandemic. Open Access Library Journal, 7, e6373. https://doi.org/10.4236/oalib.1106373 